\title{
戦後における国立総合大学設置運動にみる教育拠点形成の筣とその特質 \\ THE ACTUAL CONDITION AND FEATURE OF THE ATTRACTING MOVEMENT OF NATIONAL UNIVERSITY AFTER WORLD WAR II
}

\author{
生田国男*, 藍澤 宏**, 管原 麻衣子*** \\ Kunio IKUTA, Hiroshi AIZAWA and Maiko SUGAWARA
}

\begin{abstract}
After Torld War II, the Ministry of Education newly planned the construction of a national university to the region in which the empire university had not set it up. This plan assumed the national universities to be a highest educational institution, and aimed at the educational base formation in the location and the system in various places. The attracting movement of national universities by the activity group was done in the major city in the Chugoku region and the Hokuriku region that had become a candidate site. In the national universities attracting movement, the age immediately after end of the war, the feasibility of university establishment and the public opinion are attached to importance in the movement.
\end{abstract}

Keywords : educational base, imperial university, higher education, educatinal system, university 教育拠点, 帝国大学, 高等教育, 学制, 総合大学

1.はじぬに

日本の近代教育において国立の大学制度は、戦前の「帝国大 学命」(明治 19 年公布) に基づく総合大学としての帝国大学、 「大学令」（大正 7 年公布）に基づく官立単科大学の認可、終戦 後の「国立大学設圈法」(昭和 24 年公布)に基づく国立大学設 置一と変遷する。そして近年では、「国立大学法人法」(平成15 年公布）に基つく国立大学法人の設立が行われ、少子化高齢化 を背景として大学の組織改革や統廃合が検討されるなど、戦後 における教育制度の大きな変革期に当たると言える。過去にお ける大学制度の改革は、いずれも地域における教育拠点の形成 を1つの目的としていた注1。その改革内容は、大学が、地城の 教育樾点としての役割を、最む効果的に果たしうる立地や組織 構成が考虑されたと考えられる。今後の大学と地域社会との関 わり方を考えるうえで、現在の大学と地域社会の関俰が如何な る意図・経緯を経て築かれたものかを認識し、今後の両者の関 系性を考えることは重要であると言えよう。

戦前の教育界で中心的役割を果たし、日本の大学制度形成に 大きな役割を果たした帝国大学の保持した㮩点性に関しては、 拙稿「者拠点としての帝国大学設置の実態とその特颀」と愐 して既に発表している注2。拙稿では、帝国大学が、他の高等教
育機関に対する制度や機能面におけるヒエラルキー上の優位性 に拠り、全国と地方という2つの領城を意識した批点性を保持 していたことを明らかにした。日本の大学制度形成に大きな役 割を果たした帝国大学は、東京と、地方の主要都市 6 筒所に置 かれた。中国（広岛）・北陸（金沢・新潟）地方では、帝国議 会で設立の建淁案が可決され、帝国大学設置人大きな動きが あったが設置には至っていない注3。戦後、文部省は連合国の情 報収集機関 CIE の指導下、教育制度改革を行っている注4。改革 の結果、高等教育の機会均等を理由として 1 府県に 1 国立総合 大学を設医することになり、基本的な組織形態は現在にまで継 承されている。その経緯は、本稿第 2 章で詳述するが、国立大 学設置に至る前段階として、文部省は、帝国大学と、帝国大学 の設圈されていなかった特定地方（中国・北陸・四国）の国 立総合大学の設圈を発表している。国立総合大学設圈の候補と なった地方のうち、中国・北陸地方では、当該地方の有力県を 中心に大学の設固運動が起っている(四国では総合大学設置運 動が行われた事実を確認できない)。いずれも戦前から帝国大 学設置への動きを確認できる帝国大学配置上の空白地域であ り、これらの地域へ帝国大学に相当する総合大学を設瞋し、教 育执点の形成を目指した注 5 。以上から、総合大学設管運動は、
* 東京工業大学教育罢境創造研究センター 研究支拨推進員. 博士 (学術)

** 東京工業大学教育環境創造研究センター 教授・工博

*** 東京工業大学教育環境創造研究センター 助手. 博士 (工学)
Technical Assistant, Research Center for Educational Facilities, Tokyo Institute of Technology, Ph. D.

Prof., Research Center for Educational Facilities, Tokyo Institute of Technology, Dr. Eng.

Research Assoc., Research Center for Educational Facilities, Tokyo Institute of Technology, Dr. Eng. 
戦前の帝国大学の拠点性を継承し、戦後の国立大学の設㽬入影 警を与えたものと考えることが出来る。

大学に関しては、建築学と教育学の分野で種↔の論稿注Bが発表 されている。建築学の分野に扔いては、丸山弘幸氏が、大学キャ ンパスの設置経緯から大学の执点性を評洒しているが、大学制 度そのむのとの関連性については言及していない注?。本稿で主题 とする大学の拠点性を総合的に検討したものは拙稿「教育拠点 としての帝国大学設置の実搌とその特垻」注8 を除き見あたらな い。とりわけ戦後の国立総合大学設固運動に関しては、総合大学 設置の候補とされた各大学の「年史」にその経緯を記すものの、 文献の性格上、個別論に終始している。総じて既往研究では、総 合大学設置運動における各大学の動向に関し、歴史的な視点か ら渾動の経緯・背景・趣旨を総合的に捉え、その特䆩を論じたも のはないと言える。

以上を整まえ本稿では、各地で行われた国立総合大学設置運 動の経緯・背景・趣旨、それに同運動で地域社会の果たした役 割を総合的に捉え、戦後における教育拠点の形成過程の塞热と その特質を明らかにすることを目的とする。なお、四国に関し ては、国立総合大学設置運動が行われた事実を確諗できないこ とから、検討対象からは除く。

以下、第 2 章では、戦前・戦後に㧍ける高等教育制度の実態 とその特質に関する㭘討を行い、戦後行われた 10 国立総合大 学設置椿想の歴史的な位置づけを行う。第 3 章と第 4 章では、 実際に国立総合大学設娄運動が展開された中国・北陸地方に関 し、運動の経緯と目的を考証し、その特質を明らかにする。 なお戦前・戦後の教育制度の歴史的変遷の確認には、文部省編 『学制年史』注日 や国立教育研究所編『日本近代教育百年史』注10 用いる。また、国立総合大学設睢運動の具体的動向に関しては、 各大学刊行の年史を主な基礎资料として用いる注11。

\section{2. 戦前・戦後における高等教育制度の実態とその特質 2-1，戦前における高等教育機閔の設置状況}

文部省編集『学制七十年史』(1942 年)によると、戦前の高 等教育機関は、帝国大学、官立単科・公立・私立大学、高等学 校、専門学校から構成される。帝国大学は、総合的な分野を䂰 究対象として扱らことを根拠の1つとして、教育制度上の最高 学府として位固つけられていた。加えて、戦前における官立の 高等教育機関の昇格状況からは、帝国大学、単科大学、専門学 校の順でその序列を確認出来る主12。戦後に国立大学の母体と なる師籍学校は、師範教育のたかの学校とされ高等教育機関と して扱われていない。天野郁夫『旧制專門学校』に示される高 等教育機関数の年代別変遷の一部をまとめたものが表 1 であ る。戦前の高等教育機関の大半が專門学校であり、帝国大学

\section{表 1： 高等教育機関数の年代別变要}

\begin{tabular}{|c|c|c|c|c|c|}
\hline & 帝国大学 & $\begin{array}{l}\text { 官立蜼科·公 } \\
\text { 立·私立大学 }\end{array}$ & 高等学校 & 專門学校 & 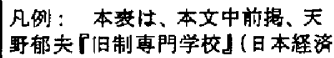 \\
\hline 明治38年 & 2 & 0 & 7 & 63 & 新閏社 1978 年) 180 百表 15 に示さ \\
\hline 明治43年 & 3 & 0 & 8 & 79 & れる高等㪘育譏関数のうち、年ご \\
\hline 大正4年 & 4 & 0. & 8 & 92 & との大学・高等学校·尃門学校数 \\
\hline 大正9年 & 5 & 11 & 15 & 106 & を抽出したものである。 \\
\hline 大正14年 & 5 & 29 & 29 & 143 & \\
\hline 昭和5年 & 5 & 41 & 32 & 173 & \\
\hline 昭和10年 & 6 & 39 & 32 & 183 & o \\
\hline 眧和16年 & 7 & 40 & 32 & 220 & \\
\hline 昭和19年 & 7 & 42 & 33 & 286 & \\
\hline
\end{tabular}

を中心とする大学の数は非常に限られたものであったことが わかる。また、昭和 10 年代に専門学校の数が急速に増加して いるが、これは「総力戦体制下での政府の強圧的な政策」注13に よるものである。「国立大学設置法」（昭和 24 年 5 月制定）に よると、全国各県に設けられた大学の前身には、すべて戦前の 制度下で設けられた專門学校を含んでおり、専門学校が全国 各地に散在していたことを確認出来る注14。

一方、全国 7 箇所に設置された帝国大学のうち、東京と京都 の場合、設立時から総合大学としての学部䔩成を確立し、単科 大学を母体としない。残りの5大学のうち、東北を除いた九州・ 北海道・大阪・名古屋の場合、それぞれ官立の単科大学を母体 として成立している。また、戦前に行われた帝国大学誘致運動 のうち、九州・新滇・広帛・金沢の 4 地域では、誘致根拠の 1 つとして帝国大学へ進学するための基硔教育を行う場である 高等学校所在地との関係が揭げられている注15。前身となる単 科大学の存在や、高等学校所在地との関保が、帝国大学設置の 1 つの要件となったことを窥える。

\section{2-2. 戦後の教育制度改革における10国立総合大学設置橉想}

戦後、日本の教育制度は連合国による指導のもと改められ た。昭和 20 （1945）年 10 月 22 日に $\mathrm{GHQ}$ が発表した「日本教育 制度に対する管理政策」によると、軍国主義・国家主義的思想 の禁止によって教育の民主化を図るという、GHQの日本の教育 改革に対する原則が示されている注10。日本の教育制度改革に は、連合国の民間情報教育局（CIE）が担当した。昭和21（1946） 年 3 月、GHQの要請により、日本における教育の実热を調查し、 その後の教育改革の具体的指針を提示する目的のもと、教育 専門家から構成される「アメリカ教育使節団」が来日してい る。同使節団は、教育の民主化に加えて、「日本教育制度の行 政的再編成」や「日本復興における高等教育」に関する調查研 究を行った。その成果は、GHQに「アメリカ教育使節団報告書」 (昭和 21 年 3 月 31 日) として発表されている。同報告書では、 戦前の日本における「高度に中央集権化された教育制度」の慗 害が指摘され、教育の地方分権化の必要性が述べられている。 同時期、CIEによって、戦前に怙ける日本の大学の大都市集中 による地方間の教育機会の不均衡が指摘されている注17。

昭和 $22 （ 1947 ）$ 年 12 月 4 日付の「東京新闆」に、旧帝国大 学と、北陸・中国・四国に新設する 3 大学を合わせた 10 総合 大学のみを官立（国立）大学とし、その他の官立の高等教育機 関をすべて地方委譲するとする記事が揭載されている。昭和 22 （1947）年 12 月 15 日の大学基準協会第 2 回総会では文部省 学校教育局次長が、「国立総合大学を、旧帝国大学の 7 校に加 えて、北陸・中国・四国に新設し、国立総合大学を全国に 10 校設置する」ことを述べている。北陸地方の金沢と新舄、中国 地方の岡山と広岛では、国立総合大学設置のための運動を展 開している。いずれの地域も、戦前に官立の単科大学が置か れ、学制で定められた大学区のなかで、帝国大学の置かれてい なかった地域である。新たな国立総合大学の設㯰により、帝国 大学立地の地域的な空白を埋めることになっている。この時 の計画は、当時の文部大臣田中耕太郎によると、大学を設犆す ることによって地方への教育の機会均等を図り、国立総合大 
学を中心に、官立専門学校を、その「衛星的学校」とするもの であったことが述べられている。具体的には、両校の間で、密 接な連絡を保ち、教授の交換を行い、学生の転学の便宜や施被 の嗵通などを図る計画であったとされる。同様に、当時の文部 省学校教育局長の見解では、「旧帝国大学その他これに類似の 総合大学を中心の学府」とし、官立専門学校を母体とする場合 を、中心となる総合大学の衛星的学校と位圈づけようとする ものであったとしている。類似の総合大学とは、北陸・中国地 方に酔かれようとした単科大学を母体とする総合大学のこと であり、総合大学とその他の官立専門学校の間に格差を設け、 組織上の従属関係を明確にすることによって、総合大学を各 地方における教育拠点とする、教育システムの構築を目して いたといえる。10 国立総合大学設立にあたっては、官立専門 学校など高等教育機関の地方委疃の実施を条件としていたが、 大学設置の基準を蕃議した大学基準協会が、「地方教育委員会 には大学を理解し運営するだけの十分な能力はない、「地方 財政には、释費負担の能力はない」と主張し、地方行政の実情 や財源不足を根拠として反対している。戦後、日本の教育に対 する諮問機関として中心的役割を果たした教育刷新委員会も、 大学基淮協会の示した根挺に加えて、官立学校を地方に委譲 することで「国土計画上全体的な見通しができなくなり、極端 な偏りを生ずる危険性がある」とし、官立専門学校など高等教 育機関の地方委変に反対している。

以上の日本の高等教育に対する諸機関の意見を踾まえて、昭 和 23 （1948）年 6 月 22 日、文部省が、「新制国立大学実施要粬」 を発表し、戦後の日本における最終的な大学設置の方針が出 されている。そのなかで「新制国立大学は特別の地域（北海 道・果京・要知・京都・大阪・福岡) を除き、同一地域にある 官立学校はこれを合併して一大学とし、一県一大学の実現を 図る」と定められている。特別の地域は、「人口数」と「大学 高専の校数」を、その根执としている注 18 。ここに限られた数 の国立総合大学を地方単位で設置し、地方委譲した専門学校 など旧官立学校の上位に位置つける計画から、県単位で官立 学校を国立総合大学として編成し、県を項域的な単位とする 多くの総合大学を設立する計画に桨更されている。この大学 の設置に関しては、「組織施設等は差当り現在の学校の組織施 設を基本として編成し遂年これが充実をはかる」とし、帝国大 学・単科大学・専門学校・師篹学校など多様な既存の目立学校 の組織や施設を国立大学として編成し、不足分を逐次整備文 ることが定められている。また文部省は、府県を単位として設 嘈される国立大学が、最初は不完全であること認めたうえで、 なるべく総合の形をとることが望ましいとしている。発足当 初の国立大学は、母体上なる教育機関の差異に伴い、学部構成 の総合性において格差の存在することを前提としていたとい える。「国立学校設世法」に記される各国立大学の学部構成か らは、東京大学の 9 学部を筆頭に、帝国大学や単科大学を母体 としている場合 5 学部以上から構成されており、帝国大学を母 体とするほうが単科大学を母体としている場合よりも多くの 学部から構成される傾向が強い。その一方で、専門学校を母体 としている場合は $2 \sim 3$ の限られた学部構成の場合が多い。母
体校の種類によって学部粠成の総合性に差が存在し、比較的 明碓な教育拠点としての差異を確認出来ると言える。10国立 総合大学設自運動の展開された中国・北陸地方の各地に圈か れた国立大学は、いずれも単科大学を母体とする5〜6学部か ら成り、総合的な学部構成となっている。10 国立総合大学設 置遾動は、戦後最終的に総合的な学部構成を持つことになる 大学を、制度的に拠点性の強い大学として確立しょうとした 動きと評価できる。

昭和 23 年 5 月以降に、文部省の指導に基ついた各大学の設狊 申請㶳が提出され、大学設置の諗可が下るに至り、中国・北陸 地方における総合大学設圈運動は終息している。

\section{3.中国地方における国立楉合大学钤置運勤}

中国地方は、学制の第 5 大区に相当し、大学本部を置くぺき 地として、应岛が定められている。当地方において国立大学の 母体組織となった官立の単科大学として、岡山の岡山医科大 学と、広岛の広岛文理科大学がある。また、両地域には、第六 高等学校や広岛高等学校といった高等学校方置かれていた。 表 3 は、中国地方における国立大学創設時の学部編成とその母 体校、各学部の設立に必要な予算積等を一筷にしたものであ る。以下必要に応じて適宜用いる。 3-1. 周山の場合注19

【戦前】岡山医科大学を帝国大学（官立総合大学）に界格さ せようとする動きは大正時代から見られる往20。大正 15 (1926) 年には、岡山医科大学と大原農業研究所とを合併し、官立総 合大学を建設する計画方立てられている。帝国大学設圈への 動きは確認されるものの、現在公にされている料は少なく 詳細を知りえない。

【戦後】昭和 22 (1947) 年10月9日、買議会から「総合大学 を設立推進に関する意見書」が提出され、会長を県会議長と する「周山総合大学設立淮備委員会」が組紐された。同会か ら文部省と国会宛てに提出された「請願書」(昭和 22 年 12 月 1 日付）に記される岡山への総合大学の設立理由は、表 2 の通 りである。岡山への総合大学誘致の理由が、大きく国家的要 因と地方的要因から述へられている。国家的要因のうち、総 合大学設立に上る文化国家の形成上教育施設の地方分散は、 戦前の日本における高等教育の国家主義的な䫅向や教育施設

\begin{tabular}{|c|c|c|c|}
\hline 目的地城 & & 两两 & 度岛 \\
\hline 国家的要团 & 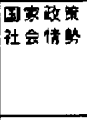 & 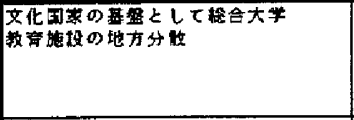 & 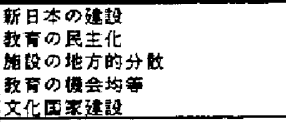 \\
\hline \multirow[t]{8}{*}{ 地方的要因 } & 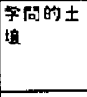 & 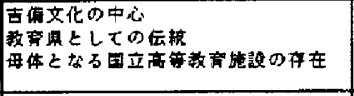 & 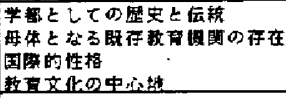 \\
\hline & 8 & & 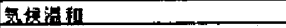 \\
\hline & 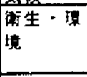 & & 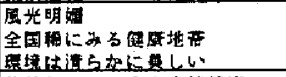 \\
\hline & 成篮 & & 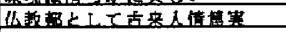 \\
\hline & 交通 & & 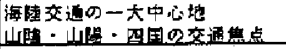 \\
\hline & 座善 & & 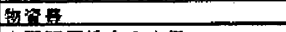 \\
\hline & 立地 & 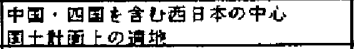 & 中国回国嵝方の中根 \\
\hline & 晊代性 & 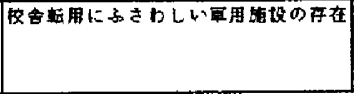 & 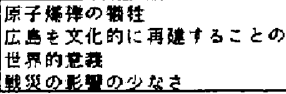 \\
\hline
\end{tabular}


の大都市集中への反省に起因するものである。また、地方的 要因としては、岡山の教育地としての通性に加えて、財政面 における実現性（校含転用にふさわしい軍用施設・市内津岛 陸軍 48 部隊跡の存在)、それに、世論の要望（全県民長年の宿 願）といった、戦後の財政難への対态や民主主義の尊重といっ た時代性を象街する内容を含んでいる。同日、委員会は、岡 山総合大学設立期成会と名称变更されている。期成会の運営母 体は、市町村撞会、岡山県教職員組合、岡山市婦人会、岡山 県青年協議会なと 20 团体である。その運動内容は、大学設立 の計画案の作成と、岡山市内、中国・四国・肘神地方、そして 東京を拠点とする署名活娌や陳掅である。

設置運野を行うための組穖としては、期成会のほか、岡山市 内に、自治体や詖会による、総合大学誘致全員委員会（岡山市 長・市議会議長を中心に構成）や総合大学謤致推進班（岡山市 媄会議員・市職員を中心に構成)、地元教育機関による、中国 総合大学岡山設立促進学生連盟や中国総合大学設立促進中等 学校生徒連盟が設けられている。これら諸団体は、岡山市内・ 県内を始め、東京（文部大臣・大葴大臣・衆参両院文教委員長・ 総司令部)、中国地方（鳥取・松江・米子）、県下各市へ協力を 呼びかけ、募金・署名活動を行っている。

岡山県下や中国地方の近隣県では、昭和 23 年 2 月 13 日に、津 山市議会が、総合大学誘致の意見書を文部・大藏雨大臣に送 り、マッカーサー連合軍総司令官やスプリンガー岡山軍政部 長に協力を要請している。また、同年1月20日に、岛根・鳥 取県議会議長が、総合大学誘致への協力を表明している。鳥取 県の場合、地元で、岡山人の総合大学誘致洂成の署名運動を決 定している。県市町村䅈会・市町村長・商工会議所・教職員組 合・婦人会の代表が、中国総合大学岡山撤致促進協議会を結成 し、全面的に国立総合大学の岡山誘致に協力することとして いる。また、同時期、鳥取農業専門学校学生代表が岡山を訪問 し、支援の意向を伝えている。

昭和 23 年 6 月、文部省により「1府県 1 大学設置」の方針が 示され、岡山への国立総合大学設罳が決定されると、期成会の 運動範囲は、岡山県下に樎小されている。総合大学の創設资金 である「施設設備充実资金」は 3 億 17 万以と定められ、全積 県民の寄付で賄われることになっている。昭和 23 年 7 月 29 日 に文部省一提出された「岡山大学設㮩認可申請書」(一部は表 3 参照）によると、5 学部を設置し、医学部は旧岡山医科大学 の立地を踏裝した市内岡地区に、その他はすべて市内津岛旧 陸軍 48 部隊跡地に設置することとしている。同申請書に収め られる「岡山大学年度別整備計画類」によると、昭和 23 年度

\section{表 3：中国地方における国立大学悀投時の学部編成と予算}

\begin{tabular}{|c|c|c|c|c|c|c|c|}
\hline 新童名 & 泝在地 & 世体接名 & 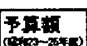 & 学部名 & 雨在地 & 四体接各 & 预量 \\
\hline 法文 & 髅山 & 宣六要学挍 & 2566 & 文 & 医量 & 迶亶文理科大学 & 849 \\
\hline 败语 & 周山 & 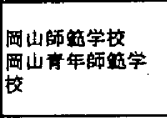 & 2530 & 灌青 & 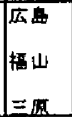 & 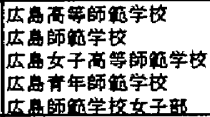 & 6654 \\
\hline I & 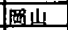 & 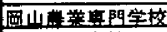 & 7950 & 些在 & $\sqrt{\mathrm{H}}$ & 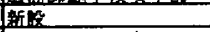 & 454 \\
\hline 理 & 瀜步 & 立六高堂堂校 & 5966 & 理 & 庶点 & 厷典文理犁大堂 & 1160 \\
\hline 医 & 奧山 & 䎟山䊈大学 & & $I$ & 空舟 & 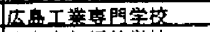 & 1582 \\
\hline & & & & 水音产 & 福山山 & 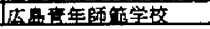 & 880 \\
\hline
\end{tabular}
ある。予算碩の算位は万円である。 $\sim 26$ 年度の 4 力年で、4 学部・本部・大学院・研究所 $\cdot$ 付属諸 学校・付属諸施設の設立に必要な予算内訳として、土地・建物・ 付帯施設・機械器具・図書購入费、それに創立事務費を計上し ている。医学部は既に整備されているものとされ予算の計上は なされていない。これらの費用を捻出するために、期成会や岡 山大学施設整備委員会は、岡山県下 ・東京・関西で基金活動を 行っている。岡山県下には、郡市単位の支部、町村单位の分会 が置かれ、踭の貫任類が割り当てられている。加えて、郡市 単位で小中高等学校校長会が、PTAに協力を依頼するなど、基 金の目標額を達成するため既存の地域組織を利用している。そ の他、オートパイ競技会・自転車競技会・演芸会の開催、農座 物の供出、宝くし・石唄販売による利益、生命保険の新規契約 の手当が大学㓣群のために当てられた。以上の活動の結果、昭 和 23 年 3 月〜 27 年 1 月の間に、約 4500 万円の募金が集まり、 加えて、2 億6100 万円を県交付金・市町村負担金といった公的 資金が执出されることになっている。

期成会は、基金運動を活発にし、総合大学設立を県民に喚起 させるため、「岡山総合大学についての柋」を作成し、新䦥や ラジオで協力を求めている。また、岡山医科大学・第六高等学 校 - 岡山師範学校・岡山農業専門学校の学生は、「岡山総合大 学建設促進学生連盟」を結成し、県下各地で新制高等学校生徒 への協力を呼びかけている。

\section{3-2. 広島の場合注21}

【戦前】大正 4（1915）年11月、広岛県会から内務大臣へ、広 島への帝国大学の設置を要望する「中国帝国大学設医意見書」 （大正 4 年「通常広島県会議事日詰」）が提出されている。翌大 正 5 （1916）年 2 月の第 37 回帝国議会租議院では、「中国帝国

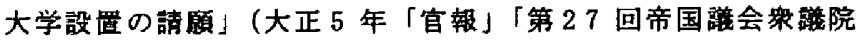
議事速記録」）が採択されたが、文部省で具体的計画が行われ す、設茞の実現には至っていない。これらの意見書や請愿書で

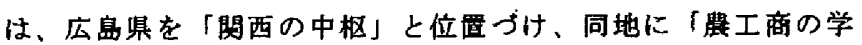
術技芸を教授する中国帝国大学」の設圈を求めている。このよ うな動きの中、大正12（1923）年には、広岛文理科大学が新 設されている。既述の通り、帝国大学は、単科大学を設立母体 とする場合が多く、広岛文理科大学の設置を帝国大学設圈人 向けた過渡的動向と捉えることが可能である。昭和 17 (1942) 年には、広岛県会加文部大臣宛てに「官立総合大学設㯰意見 書」(「通常広岛県会議事日誌」) が提出されている。同㶳には、 「中国・四国地区の政治・経済・文化の中枢地」・「急激に勃興 せる大工業地帯を摭し」と記され、広岛の地城性が評価されて いる。加えて、総合大学設置の根圾を、「大東覀共栄圈の指迸 者を荃成」・「高度国防国家建設上必缺の施設」・「大陸・南方释 営進出の起点」といった戦時的要因に求めている。

【戦後】広盘における国立総合大学設狊運動は、昭和 22 (1947) 年1月の県政座談会で国立広岛総合大学の設置に関す る議案が採り上げられたことを契機とする。広岛県会からは、 文部大臣なとに宛てて、「広島総合大学設立認可に関する陳情 書」(昭和 22 年 8 月) や「官立広我総合大学設置につき申請」 (昭和 22 年 10 月 14 日) といった、総合大学誘致の趣旨や根拠 を記す文書を提出している。各文書に記される主な内容は表 2 
の通りである。総合大学設立による文化国家建設、教育の民 主化、教育施設の地方分散の必要性に加えて、戦前の軍都で あり、原爆による大きな被害を受けた広岛に、民主主義や平 和を象街する国立総合犬学を設置し、文化的に再建すること の世界的意義が述へられている。同時に、母体となる教育機 関の戦災からの復興を強調し、設立の実現性が主張されてい る。

国立総合大学の設㯰を実現するために、国立広岛総合大学設 立推進本部（昭和 22 年 12 月 23 日設立）と広島総合大学設立期 成同盟会（昭和 23 年 1 月 12 日設立）が設けられた。推進本部 は、本部長を県知事とし、県関保者や、大学設立地となる広 岛・颔・福山市関保者、それに広岛文理科大学以下、統合教育 機関関保者を役員としている。その活動内容は、総合大学の建 築・設備・数地・建筑資金の計画に関することである。すなわ ち、総合大学創設に関わる具体的な計画に関しては、推進本部 が主に行っている。また、基金、世論喚起、国会・関係省庁 ・ $\mathrm{CIE}$ - 広岛軍政部への陳倩といった誘致活動にも参している。 一方、期成同盟会は、会長を広岛県会議長とし、役員を、各市 長、県下商工会議所、町村会長、県市議会、財界、各種団体、 官公庁代表、学校側代表とする。主に、募金、世論喚起、中央 人の陳情といった活動を行っている。同年 12 月 24 日、再会に

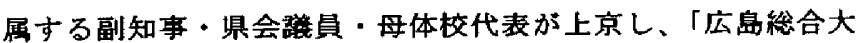
学設立計画書」(昭和 22 年 12 月 26 日付）を文部省やCIE 提 出し、陳情を行っている。このときの計画書には、設立骐意・ 構想 - 施設概要 ·設備概要 - 学科内容・講座数・学生定員・建 物平面図が示され、設立後の大学像を具体的にしている。同計 画苦では、広岛文理科大学など8校の母体校を併せて、文学部・ 理学部・教育学部・工学部・医学部・水䱜産学部 6 学部々教 羡部を編成することとしている。推進本部や期成同盟会の作 成によるこのような計画書は、改正が加えられ「広島総合大学 設立計画書」(昭和 23 年 1 月 15 日付) や、その直後に「広岛総 合大学設立計画書」としてまとめられた。これらの計画書で は、女子学部や教育学部の設圈といった学部椣成に異同が見 られる。大学設立のため文部省に提出された「国立広島総合大 学設置申請書」(昭和 23 年 7 月 25 日付一部は表 3 参照) では、 立地や施設上の不備から医学部が別申請となり、文部省や母 体となる広岛県立女子尃門学校の了承が得られず女子部の設 置は保留とされている。設立当初の広島大学は 6 学部から構成 され、その多くは体校の立地を継承した広島市に立地する ことになった。教育学部は、母体となった師範学校の立地を反 映し、広島・福山・三原の各市に分置されている。同申請書に よると、昭和 $23 \sim 27$ 年度の 5 カ年で必要な大学創設費（像設 事務費・新営費・補修費・設備費・買収費）は 2 億 7 千 401 万 円とされる。集計されている年度が相違することから、経費の 内訳を対応させることは出来ないが、同申請書に収められる 「新制大学総経費調」によると、昭和 $24 \sim 28$ 年度に、6 学部・ 教盖部・本部・中央図書館を整備するために必要な費用は I 億

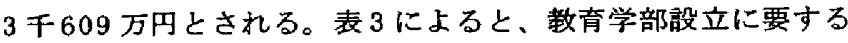
費用が他学部に比較して多いが、これは前揭「国立広島総合大 学設立資金隼趣意書」によると、「わが国で最も完整した教
育学部」となったことによるものとされる。以上の費用は、県 費 3 分の 1 、一般寄付金 3 分の 2 により負担することになって いる。一般寄付金に相当する募金に関しては、推進本部で、全 体方針・実施方法が決められている。募金活動には、推進本部 の関連組織である期成同盟会や国立広岛大学設立促進会も携わ り、その対象地域は、広岛県内外を始め、海外にまで及んでい る。㐞金のために、郡市別基金割当額が定められ、地域組織に よる活動が行われている。県下の町村役場には、募金本部が圈 かれ、町村議会・学校長・青年団是・婦人部長・民生委員から なる算金委員会が結成されている。京阪神地方には、国立広島 総合大学設立期成会近畿支部、京阪神芸備会が圈かれ、基金活 動を始めとする設置運動展開の䞗点としている。「国立広島総 合大学設立期成同盟会収支決算中間報告」による昭和 23 年 1 月〜 27 年 9 月までの一般㟢付金の額は 7034 万円となっている。

県下の募金活動を稙極的に展開するために、昭和 24 (1949) 年 2 月、各郡市・町村別に募金協謱会が置か扎ている。募金は、 総額の 6 割を地元、残り 4 割を他の郡市に配分している。BCD 地区においては、その6 割を平等割に、残り 4 割を近接地（BC） 地区に配分し、各地区別平均一世带負担額を定めている。

以上の地域組織を利用した㐞金活動に加えて、推進本部や期 成同盟会は、広盘県教育宝くじの発行や、県下各地人の演芸班 の派遺を行っている。総合大学の母体校や、県下の諸学校では 学校募金が行われ、同時に、スポーツ・音楽・演剧・バザーに よる基金運動が展開されている。

これらの募金運動への世論喚起のために、ポスターや「国立 広岛総合大学設立资金募集趣意書」が作成され、県下に配布さ れている。また、県民・各方面人寄付依頼状加送られ、新䦙・ ラジオ・ポスター・立看板による広報活動が行われている。

以上、中国地方では、総合大学建設のために期成会を結成 し、母体校を編成し総合大学の組織計画を行い、世論唤起、署 名活動、催しや地域組織を活用した㓣設資金の獾得、それに国 や連合国に対する陳情を稙極的に行っている。侯補地のうち岡 山では、転用可能な旧軍用地の存在と、県民による総合大学設 圈の要望が大学誘致の根执として主張されている。一方、広岛 の場合、原爆による被災地として、総合大学の建設による平和 的文化都市建設の世界史的意羲が主張されている。広島大学 は、母体校の立地を継承しキャンパスが分散し、岡山の場合、 旧軍用地の利用によるまとまったキャンパスを獾得している。

\section{4.北陸地方における国立彩合大学設贯運動}

北陸地方は、学制の第 3 大区と第 7 大区に相当する。両大区

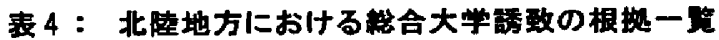

\begin{tabular}{|c|c|c|c|}
\hline 工地蝴 & & 全讯 & 新埧 \\
\hline 国家的豆因 & 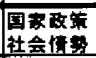 & $\begin{array}{l}\text { 单和・文化国家の形成 } \\
\text { 大学の地方公散 } \\
\end{array}$ & 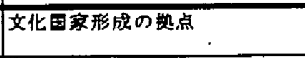 \\
\hline \multirow[t]{6}{*}{ 地方的㗐因 } & 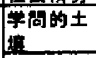 & 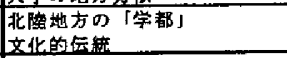 & 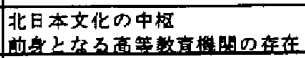 \\
\hline & 交湴 & & 海隐文晒の要行 \\
\hline & 应果 & 座菜の独自性 & 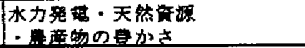 \\
\hline & 立地 & 北盐地方の「雄都」 & 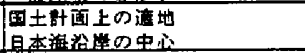 \\
\hline & 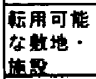 & 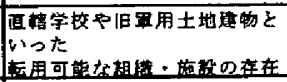 & \\
\hline & 時代性 & 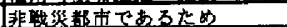 & \\
\hline
\end{tabular}


の大学本部は、第 3 大区を石川、7大区を新潟に設固すべきも のとされている。戦前の北陸地方に㧍ける高等教育機関の設固 状況として、石川に、金沢医科大学と第四高等学校が、新潟に、 新潟医科大学と新渇高等学校といった、官立の单科大学と高等 学校が設けられている。表 5 は、北陸地方における国立大学創 設時の学部編成とその母体校、各学部の設立に必要な予算積等 を一筧にしたものである。以下必要に匛で適宜用いる。 4-1. 石川（金沢）の坦合注22

【㦸前】石川累の県庁所在地金沢人帝国大学を譑致しようとす ろ動きは、明治40（1907）年8月15日付の「北国新問」紙上 で、金沢出身の科学者高蜂㩧吉が、当地一の帝国大学設立を提 唱したことに始まる。明治 44（1911）年2月 2 日の第 27 回帝

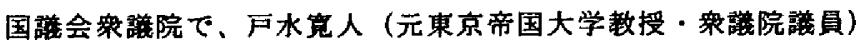
加「北陵帝国大学設立の建碚案」が提出され、同月 18 日に 同竬案は可決されている。これに伴い、同内部委員会で、既存 の大学・高等中学校の立地との関保や、金沢の学問渨境が検討 されたが、設圈の実現には至っていない。

金沢一の帝国大学設立の建就案は、第 51 回帝国碚会衆譜院 （大正 15 年）、第 52 回帝国礒会衆議院（昭和 2 年）、第 56 回帝 国碚会监議院（昭和 4 年）でも提出され、第 52 回と第 56 回分 の建竦案は可決している。第 52 回提出分の建偁案によると、 「金沢付近は全国最雨量多き部分に属す湿気に関する気象上生 物学上医学上物理化学工学上の問題にして特殊の攻究を要する もの極めて多く」とあり、帝国大学におけける学問対象として、 金沢の気候の特殊性を扱うことの意義が述べられている。

【戦後】石川県会や金沢市会は、国会や中央の関保官庁に、 「総合大学に関する意見書」(昭和 21 年 2 月、文部省・大藏省 一提出)、「北陸大学設立趣意書」(昭和 23 年 6 月 3 日、内務大 臣 - 文部大臣 - 大藏大臣入提出)、「金沢市に北陸帝国大学を設

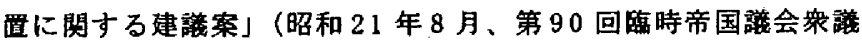
院人提出)、「総合大学設置に関する請願書・陳情書」（昭和 22 年 8 月、第 1 回国会人提出）といった、金沢一総合大学を誘致 するための趣旨や目的を記す文書を提出している。各文書に記 される主な内容は表 3 の通りである。総合大学の設立理由のう ち、国家的な要因として、総合大学設立による平和的で文化国 家の建設、大学の地方分散の必要性を述べている。また、金沢 に特徽的な地方的要因として、非戦災都市であり、官立学校や 軍用土地建物なと転用可能な組織・施設の存在による総合大学 設立の害現性が考庶されている。

昭和 $21 （ 1946 ）$ 年 6 月、石川県庁に、設固運動を行うための北

京 5 ：北陸地方における国立大学創設時の学部編成と予算

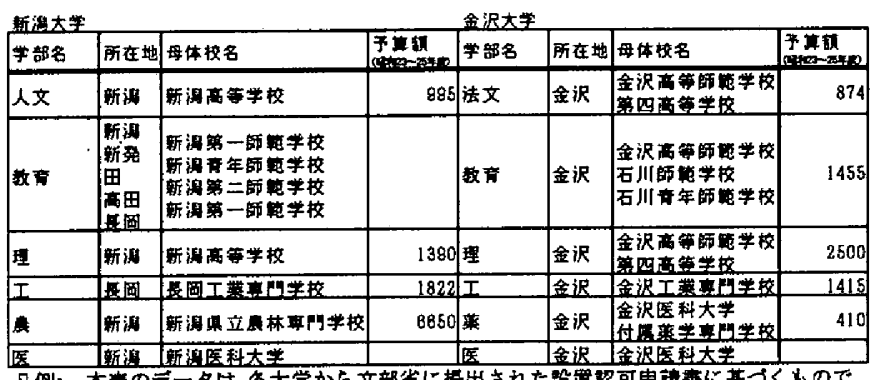

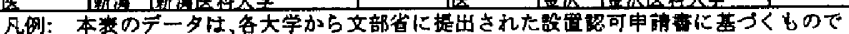
おる。千算数の策位は万円である。
陸総合大学設置期成同盟会が展かれている。会長は石川県知事 であり、石川県商工経済会会頭、金沢市長、金沢市内の各学校・ 教育関保者・地方官公庁・実業経济界関保者、富山や福井累の 知事・市長・商工経済会会頭などが㟲問になっている。同盟会 の主な活動内容は、総合大学の組織計画、㓣設盗金の確保、北 陸地方各累を対象とした㤵萣活動、中央への陳情である。

昭和 22（1947）年 11月、同盟会は「北陸総合大学設立淮備 委員会」と名称を変更している。その際、準備委員会の活動範 囲は、石川県を対象とするものに維小され、活動内容は、刷設 金の確保、敷地の確保や組織編成の検討など総合大学設立の 準備を進めることに重点が圈かれるようになっている注23。昭 和 23 （1948）年 1 月 13 日、石川県首膎部と県議会教育民生委 貝により、大学創設費は地元負担と定められ、募金運動は、北 陸総合大学設立準備委員会を中心に進められている。大学㓣設 のための奇付金の㐞集額は 2 千 300 万円であり、その負担は、 県下の各郡市（金沢市・小松市・七尾市・江沼郡）、東京、関 西一割当てられている。「金沢大学創囅奇付金調」（昭和 24 年 6月10日付)によると、寄付金納入済額として412万円が記さ れている。同年 5 月 10 日〜 16日と、11月21日〜26日は、大

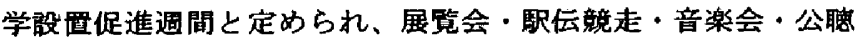
会の開催、ラジオ放送、教育宝くじ販克、ポスター貼讨、立看 板群圈、街頭宣伝・街頭放送が行われている。

「金沢大学設置認可申請書」（一部は表 5 参照）によると、大 学発足時、6 学部を設置し、本部の度かれた金沢城跡の旧軍用 地とともに、金沢市内の母体となった 7 学校の用地を用いると している。同申請書に収められる「創設費総計表」によると、 昭和 $23 \sim 25$ 年度に創設のために必要な費用（営繥費・設備費） は8千600万円とされている。5 学部の設立に必要な費用に加 えて、奇宿舎の設赛費や事務費も計上されている。医学部は既 に整備されているものとされ予算の計上はなされていない。同 表によると、これら費用の財源は県負担とされる。金沢大学創 設のために県費と寄付金が用いられていることを確認できる。 4-2. 新潟の場合注 24

【戦前】明治 35 （1902）年の「東北日報」で、建部澱吾（蒲 原郡横越村出身・東京帝国大学教授）は、「北越帝国大学」を、 帝国大学の設置のない車日本（新鳰）へ設置すべきと述べてい る注25。その後、昭和14（1939）年12月14日に、「新潟県に総 合大学設圈に関する意見書」が、新潟県会から総理大臣へ提出 されている。意見書では、新鳰への帝国大学誘致の根拠として 建部遯吾の揭げた理由に加え、地域性（人情風俗又教厚）、学 問的土䘫（大学進学者の他地方への流出、母体となる高等教育 機関の存在）、時代性（大陸経営の拠点）が述べられている。 【戦後】戦後の新渴における総合大学誘致への動きは、昭和 20 (1945)年12月17日の新鳰県議会に就いて渡辺常世が、同 県村松・新発田の兵含を利用した総合大学設置の提案を行った ことに始まる。昭和22（1947）年12月28日の「新鼬日報】で は、松井正夫（新潟高等学校校長）が、全国の大学所在都市の 戦災を根拠として、被害の少なかった地方（新潟）八大学の分 散を提案している。さらに、田中貞次（長岡市出身、東京帝国 大学農学部教授）は、新潟医科大学を母体とする医学部、「我 
国第一の米産県」という地域性とともに、戦後の食粞難という 時代性を根拠とする農学部の設置を提㕷している。 文部省により 10 総合大学設置棒想が出されると、昭和 22 (1947) 年6月 29 日には、国立総合大学設遭運動の中心的な役 割を果たす北日本大学期成同盟会が結成され、本部が、新舅医 科大学に置かれている。会長は、県知事であり、役員や噼問と して、県議会議長や県連合青年団長といった地元の有力者、元 法相や東北大総長といった中央や近隣の有力者が名を連孙てい る。期成同盟会には、促進運動委員会（国会議員・県市の理事 者・財界・教育界の主要メンバー、裝内有力者)、基硔調查委 員会（県下各高専校）といった、内部委貝会が設けられ、奏 際の活動には、医科大学教官・学生、新潟高等学校教官が従事 している。また、期成同盟会には、地区機構が設げられ、地区 支部（市長・母校学校代表者など） $\rightarrow$ 郡市支部（町村長会・各 学校長・教組・青年団・婦人会・各労租・農商工組合・文化団

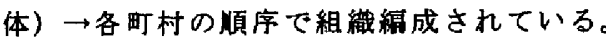

期成同盟会の作成した「北日本大学期成同盟会趣意書」（昭 和 22 年 6 月 29 日）に記される主な内容は表 4 の通りである。総 合大学の設立理由のうち、国家的な要因として、総合大学設立 による文化国家建設の必要性を述へている。また、大学誘致の 根执が、終戦直後の時代性や、新潟の地域性に基づき示されて いる。「北日本総合大学の構想」（昭和 22 年6月 26 日）では、趣 意書の内容に加えて、敗戦に上る教育の改革と再建の必要性咕 述べられている。また、総合大学設置を実現するためには、「政 府のカにすがると言ふが如きことは今日の奏情では絶対不可 能」、「举県一致の御支援を希望し期待、県内末端に迄浸透せん ことを念願」とし、地方に扔ける国立総合大学の創設责捻出 と、世論喚起を重視している。さらに、同年 12 月 24 日には、 「国立総合大学設固促進に関する意見書」が、県譜会から文部 大臣に出されている。同書では、「文化施設の再配坦、地方分 散」を述へ、「青年学徒が各地の大学に殺到する」状況を避け るために、「人情風俗又就厚、教育地に適し、歴史的に文化の 中心」である新渴人の大学設立を希望している。

期成会は、総合大学誘致の実現に向けて、中央への陳情や、 地元での啓蒙活動を行っている。同年1月16日に、期成会の 教育部長が上京した際、文部省の学校教育局長は、総合大学設 立に扔いて、国请から、現在ある施設を拡充させる方針を述 ヘ，基金を集め、䑤地を買収し、施設その他の具体化を図るこ とが急務としている。そこで期成同盟は、資金計画を行うため の組織として、㗄金造成計画専門委員会が設置され、大学創設 に必要な資金を 1 億 3 千万円と定めている。期成同盟は、地区 機構を通した㐞金活動の他に、同年 2 月 11 日から 1 䓢間、アー ニー・パイル舞踏団の公演を催し、その利益を大学㓣設資金に 宛てている。また、新潟医科大学は、音楽会・演劇・紙芝居を 催し、県下各地一無料診療班を派遗し、その収益を総合大学剖 設資金に充てている。以上の募金運動に併せて、県連合青年団 は、通信教育や教養講座を催している。また、期成同盟会は、 累内に「北日本総合大学に就いて県民の皆様への御願い」と題 する宣伝ビラを配布し、国立総合大学設圈運動の歌を制作する など世碖喚起を行っている。
新潟への総合大学誘致においては、戦後に連合国が行った日 本の教育改革に大きな影锌力を有したGHQ 東北軍政部民間情報 部教育部長マーチン博士の果たした役割が大きい。彼は、その 管犗下にあった新渴を、「東北・北海道・関東の範囲内で総大 設置に極めて必要な場所」と位圈つけ、新潟に総合大学を誘致 することの重要性を、大学の設立決定に大きな力を持つGHQの イールズ、文部・大藏両大臣、国会の大学設置委員長に働きか けている。同年 3 月 20 日〜24 日にかけて、期成同盟会委員が 上京し、政府（森戸文部大臣）・国会・各省庁 (文部省・大藏 省物価主計局長)・GHQ（マーチン、イールズ、教育担当者）上 の間で、新舄人の国立総合大学設圈に関する会談を行ってい る。同会談中、「新舄の運動は出来るだけ助けたい」(イール ズ)、「(北日本総合大学の設置) を完全に指示する」（マーチン） と、新潟への国立総合大学の設圈に対する軍政部の肯定的な意 見が出されている。軍政部の示した北日本総合大学誘致の根拠 として、マーチンが先に示した「総大設㯰」上の重要性に加え、

1、国立総合大学の設立による文化国家の建設、産業への寄与

2. 非戦災都市としての存在

3. 全国一の米産地、農産地として充実した施設の存在 設立害現への条件として

1. 新潟・長岡・高田間における学生輸送の便宜の確保

2. 教育者と全県民による関心の必要性

といった事項を示している。

昭和 23 年 6 月 29 日付で大学設置準備委車会から文部省人「国 立新潟大学認可申請書」(一部は表 5 参照) が提出され、新潟 への総合大学の設筈が内定している。同書によると、教育学部 や教盖部を新潟・長岡・新発田・高田の 4 力所に、工学部を長 岡に、人文・教育・理・農・医学部を新舄に設置することとし ている。その多くは新溤医科大学ほか母体校の立地を継承し新 潟市に置か九ている。教育学部や教荃部の分散は、設立対象と なる新潟県の領域性や、母体校の立地を継承し設置を希望する 各地の地方感情を考虑したものとされる。これらを設立のため の新校舎の建築費や物件费として、昭和 $23 \sim 25$ 年度に、1 億 2877 万円の予算が計上されている。医学部と新舄キャンパス の教育学部は既に整備されているとされ予算の計上はない。こ れらの費用は、奇付と県費によって賄われたが、管見の限り、 その詳勫は明らかでない。昭和 23 年 10 月 4 日、文部省が大学 設置の可否を判断するために設けた大学郡罡委員による現地視 察が行わ机、キャンパス分散が、大学弱体の原因となることを 指摘しておう、文部省としてもキャンパスの統合を志向してい たことを窥える。昭和 24 年 6 月には学内に一般教養委員会が 発足し、教養部の新潟地区集結の意見が強く出されている。こ れは先に軍政部が示した学生輸送の便宜の確保によるキャンパ ス間の効果的な交流が生まれず、新潟以外の地では、請義開催 に支障を生じ、教官不足から所定の単位修得も困難な状況と なっていることによる。そのため母体校の立地を継承し多くの 学部の置かれた新鳰集中へ移行することになるのである。昭和 25 年 3 月 15 日に開かれた新潟県議会によると、長岡・新発田・ 高田へのキャンパス分散は地方文化の向上と教育の機会均等を 目指した県や市民への大学側の公約であり、教養部の新舄集中 
人の動きが大学設置の本来の趣旨に悖るものであることが指 摘されている。昭和 25 年 3 月、新潟県知事・新潟大学学長・新 潟県教育委員長・新潟県会議員の共同署名のもと教養部の新 潟集中を実現するが、同時に、大学は、教育学部の現状維持 を県や各市民に確約する結果となっている。新潟大学のキヤ ンパスが、新捣県の領城性や、体校の立地に加えて、地域 社会と深い関わりをもって存在していたことを窥うことが出 来る。

以上、北陸地方では、総合大学建設により平和的文化国家の 形成を目指している。期成会は、体校を統合し大学の組織 計画を行っている。同時に、世論喚起、署名活動、催しや地 域組織を活用した㓣設盗金の獾得、それに国や連合国に対す る陳情を稙極的に行っている。侯補地のうち金沢は、転用可 能な軍用地の存在、文化・産業の特異性を誘致の根拠とし、新 渴の場合も同地における農業の発達を設立の根拠としている。 新潟の設立释緙やキャンパス分散の経稦からは、連合国によ る影響と共に大学と地域社会の強いつながりを窥える。

\section{5.おわりに}

戦後、連合国の指導下、文部省は、官立学校の大半を地方委 讓し、旧帝国大学に加えて、新たな国立総合大学を設けるこ とで、大学の大都市集中を解消する10 国立総合大学設立棈想 を提案した。同構想は、国立総合大学を教育制度上の最高学 府と位置つけ、各地における立地・制度・機能上の教育攵点 形成を目指すものであった。

新たな総合大学設置の候補とされた中国・北陸地方では、各 地方内の主要都市が設置の候補地となった。設圈の侯補とさ れた両地方の各都市は、戦前から帝国大学設置人向けた動き が見られ、帝国大学（国立総合大学）設置の適地として一貫 して認識されていた。同時に、新たな総合大学の設圈が、戦 前の帝国大学配置の空白を埋めようとする動きであったこと を窥える。

国立総合大学設置の候補となった各都市では、期成会を活動 主体とする国立総合大学設圈運動が展開された。期成会は、国 立総合大学の設置により平和的文化国家の建設を標榜し、大 学の地方分散を目指した。国立総合大学設置運動では、終戦 直後という時代性や、国立総合大学設立の実現性に関する項 目、それに民意の総意に基づく運動であることが重要視され ている。

最終的には、多くの大学を府県単位で設置する 1 府県 1 国立 大学設置人方針変更が行われたが、国立総合大学設立の対象と された各地では、官立単科大学などを体とする学部構成によ り分野的な総合性を確保できている。同時に、母体校の立地に 影製される形でキャンパス分散問題の萌芽を見いだせる。

注

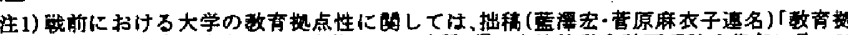

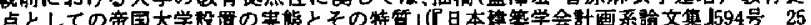
$\sim 32$ 而 2005 年8月)で明ら吃している。

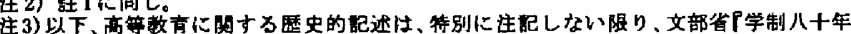

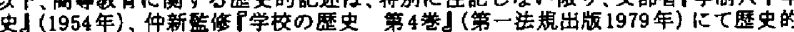

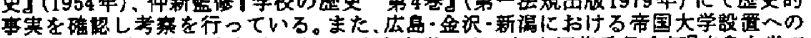

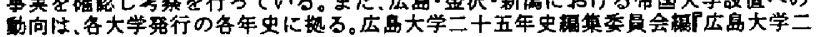

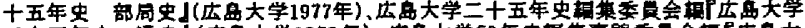

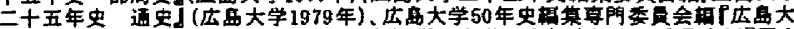

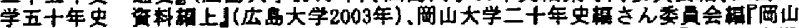

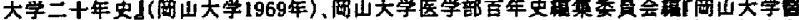

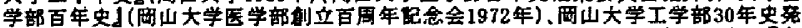

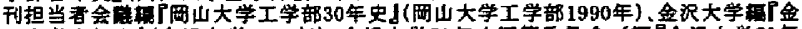

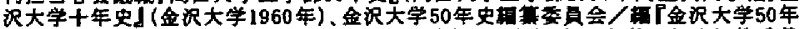

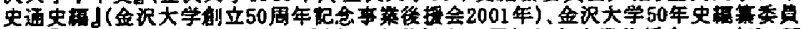

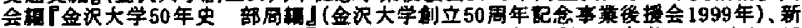

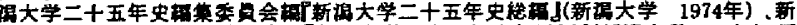

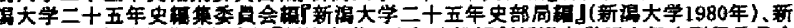

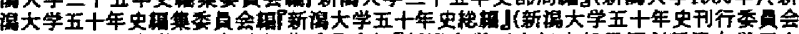

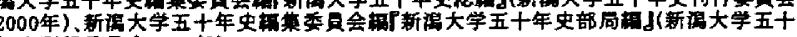
年史刊行番全2000年)

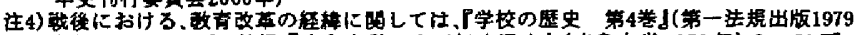

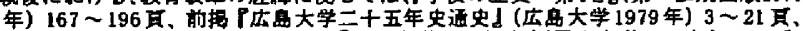

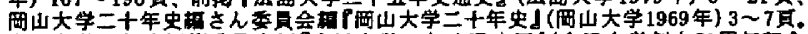

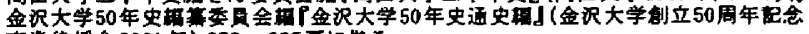

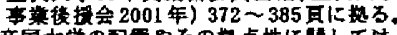

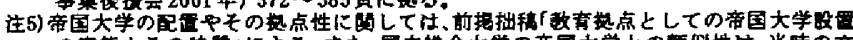

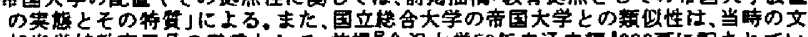

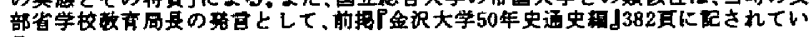
3.

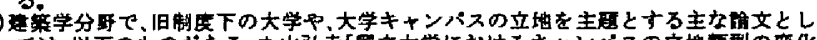

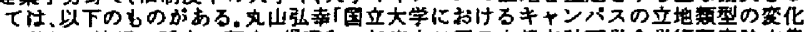

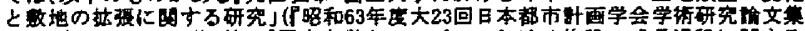

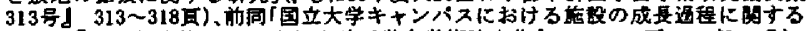

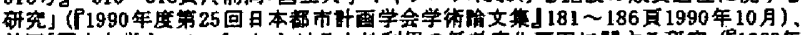

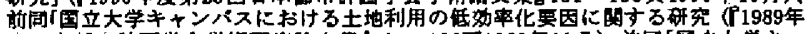

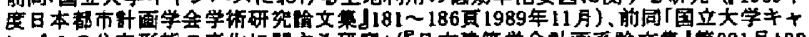

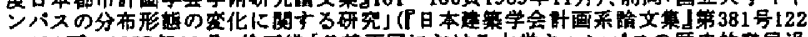

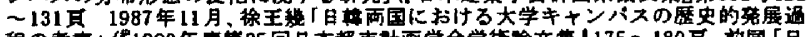
䅛の考策」(

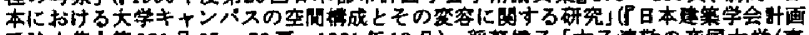

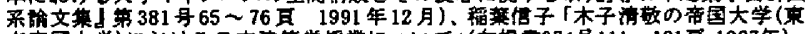

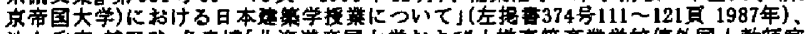

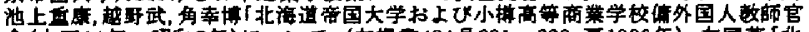

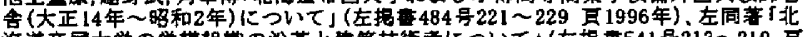

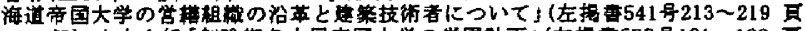

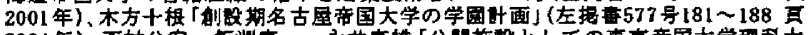

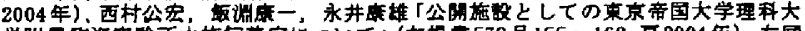

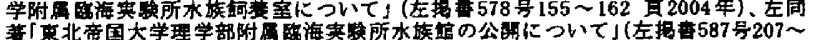

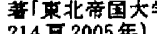

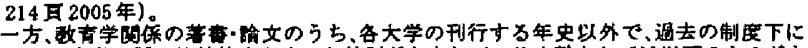

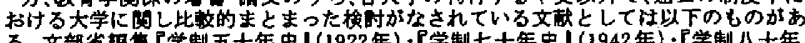

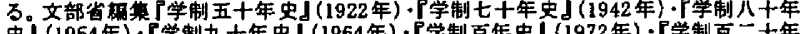

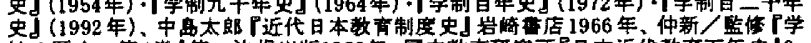

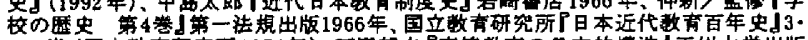

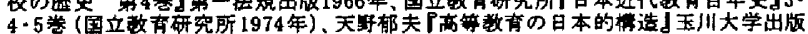

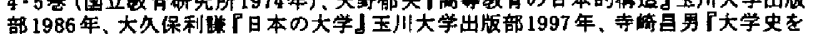

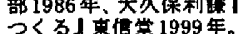

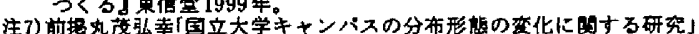

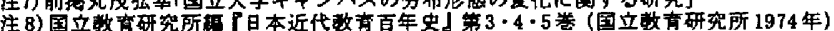

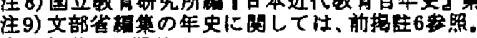

注 10)都1同已

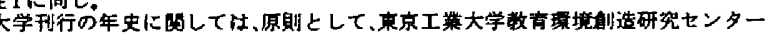

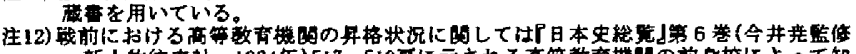

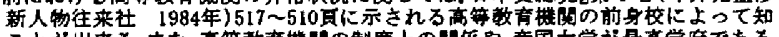

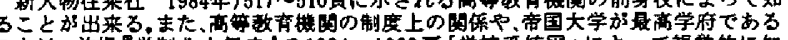

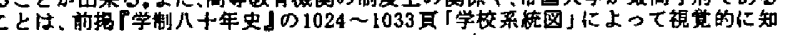

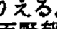

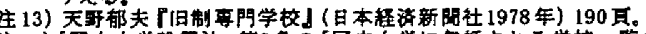

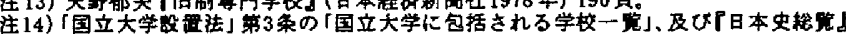

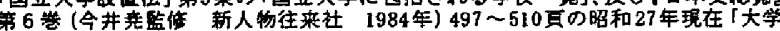

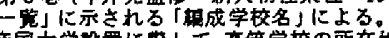

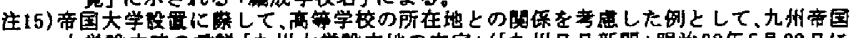

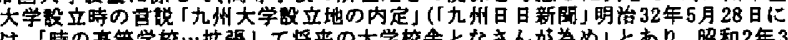

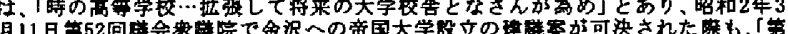

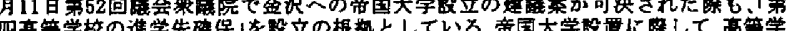

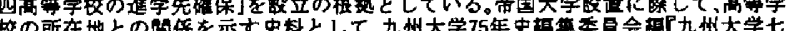

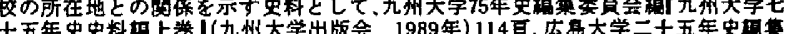

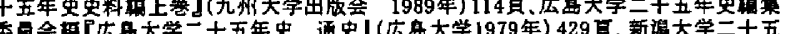

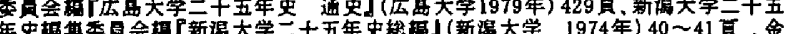

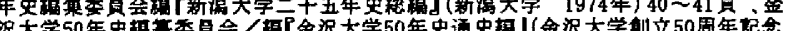

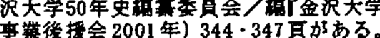

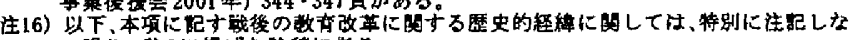

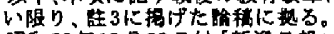

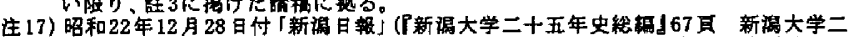

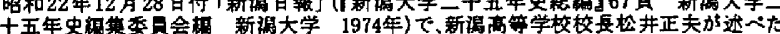

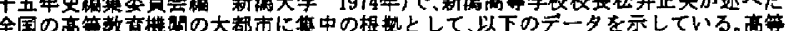

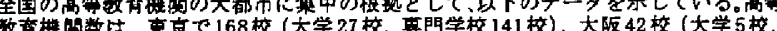

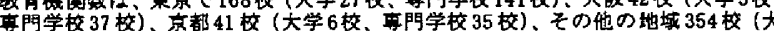

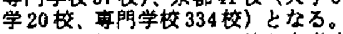

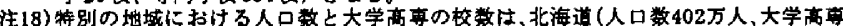

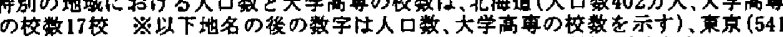
万人 169 知 (322万人,21 万人，16920

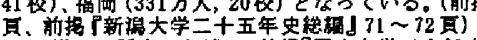

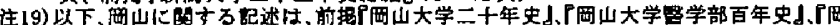
山大学工学部 30 年史』に施る。

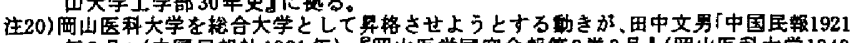

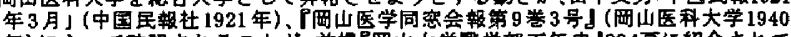

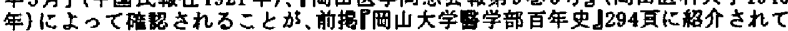

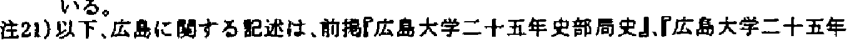

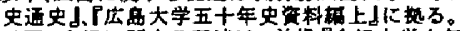

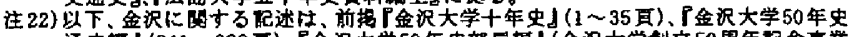
通语 後据会1999年) 认势万。

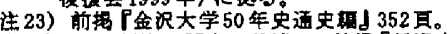

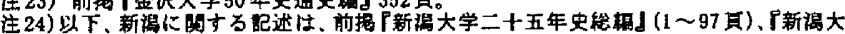

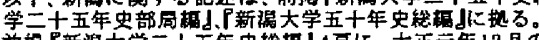

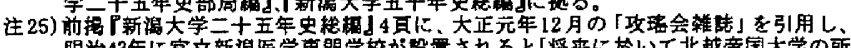
在地たるを期せさる゙ンからすと述へている。

(2005年 6 月 8 日原稿受理，2006年 2 月 9 日探用決定) 